\title{
Spiritual education of growing generation in the out-of-school education institutions of modern Ukraine
}

\author{
Yu. S. Shulha \\ Sumy state pedagogical university named after A. S. Makarenko \\ Paper received 26.04.18; Accepted for publication 01.05.18.
}

\section{http://doi.org/10.31174/SEND-PP2018-164VI68-13}

\begin{abstract}
The article reveals the peculiarities of spiritual education of growing generation in the out-of-school education institutions of modern Ukraine. The concept of Sunday school as a type of the out-of-school education institution is defined. The role of the Sunday schools in the process of spiritual education and upbringing of the growing generation is defined. The tasks and activity of Ukrainian Sunday schools of different confessions are characterized. The forms of work with children at Sunday schools are analyzed.

Keywords: spiritual education, out-of-school education institution, children, Christianity.
\end{abstract}

Introduction. The history of the Ukrainian people is closely connected with the history of their religion. It is difficult to overestimate the thousand-year contribution of Christianity in the formation of the mentality of our people. One of the directions of the cultural and educational activity of the Orthodox Church in Ukraine was its educational activity. It was manifested, first of all, in the creation of a large number of education institutions, namely: the schools of grammar, parish schools, bursy and theological seminaries that opened the way to the world of knowledge for the prominent Ukrainian people and cultural elite. These first schools also shaped the church community, in which the students were formed as Christians.

With the separation of the Church from the school, the inheritance of Christian pedagogy was also lost. The system of Soviet education tried to replace and eradicate Christian pedagogy and its methods. But with the restoration of the statehood of Ukraine, its people again returned to the original source of its spirituality - the Church.

A brief review of publications on the subject. The problem of spirituality has always occupied an important place in science. The problem of spiritual education was reflected in the publications of not only teachersresearchers (O. Vyhovska, L. Henik, K. Zhurba, I. Ohiienko, Yu. Shcherbiak and others), but also in the works of philosophers of the past (M. Kagan, S. Crimean, O. Uledov) and modernity (S. Proleiev, L. Sokhan, O. Yatsenko). Psychological aspects of spirituality are reflected in the works of psychologists (B. Gal, L. Vyhotskyi, O. Zelichenko, M. Savchin and others).

The goal of the article is to analyze the theoretical foundations of the stated problem and, on its basis, to study peculiarities of formation of the spiritual values of the growing generation in the out-of-school education institutions.

Materials and methods. In the article the following theoretical methods were used: theoretical-methodological analysis of the research problem, systematization of literary sources on the problem, comparison, and generalization of data.

Results and discussion. For the last decade, Ukraine has been experiencing a deep crisis that has covered all the spheres of public life. In search of ways out of this crisis, in public consciousness the idea is formed that one of the main means of overcoming crisis is improvement of spiritual world of the person. In this regard, the views of statepolitical and cultural figures, as well as scientists, increasingly turn to traditional, long-standing institutions and, above all, church institutions, which are still cells of spiritual education in Ukraine.

The problem of spirituality has always been relevant and has occupied an important place among various scientific and humanitarian branches. In modern science, the issues of spiritual education are increasingly raised because it has a great influence on the formation of the personality of the younger generation. Firstly, it is a component of world culture, knowledge of which is necessary for every educated person. Secondly, it is a universal value that can make a child's life full of meaning, decency. That is why the spiritual upbringing of each individual is a general picture of society's spirituality, on which the basic vector of its sociocultural, economic and political development largely depends.

The concept of spirituality is explained by the researchers in different ways. This phenomenon is complex and multifaceted. Spiritual life basically covers the processes of upbringing, education, science, culture, literature, art. Its essence is reflected in the realization of spiritual needs and interests of a person, his views, thoughts, phenomena, social processes, concepts [1, 8-9].

For centuries Orthodoxy was a culture-forming, spiritual principle, on its basis moral foundations, etiquette, family, social relations were created. Therefore, it is natural to refer to the pedagogical heritage of the Church. Sunday schools are not only education institutions, the priority here is upbringing and development: spiritual, moral, creative and intellectual. Spirituality in the Orthodox understanding is activity, the disclosure of the whole potential of a person, the opportunity through the service to become the image and likeness of the Creator.

A. Vyshnevskyi points out the need to revive spirituality and intelligence as the main priority of modern Ukrainian education [2, 21]. He notes that school must turn "to the sources of spirituality, to everything that makes our work, our life inspired, illuminated by faith with hope. Since the Church is the main source of spirituality, its cooperation with the school is not only possible, but also necessary" [2, 21]. Spiritual education positively influences the general moral state of Ukrainian society, because it is based on Christian morality.

Because of Christianization of the society, the need to create Christian schools had increased. Sunday schools (catechetical) began to appear. These were the first Christian education institutions, folk schools, "schools of life". Their goal was to introduce Christian concept to children, 
to teach the Christian way of life and bring them up on its best traditions [3, 15].

Having created its system of upbringing, Christianity laid a serious foundation for the development of its own original pedagogical theory [3, 16-17].

The Church attaches great importance to education in the life of a person, its influence on the progress of modern society. It recognizes the right to help the development of education. Actually, the right [4, 353] imposes on the Church the duty in various ways to help parents in the spiritual education of children, especially the catechism and the organization of Christian schools [5].

In our time, educational centers that are most conducive to the spiritual education of the individual, its integral formation, are Christian general and Sunday (church) schools. It should be noted that the term "Sunday school" is conditional and does not mean literally a school, classes in which occur only on Sundays. This concept is mainly used in regard to schools, more precisely, to the education system where the spiritual component dominates, that is, the central axis of which is the Law of God, morality and high Christian ideals, and all other subjects that are taught in its framework are applied derivatives of these fundamental. But the main thing, on which education in Sunday schools is based, is the priority of spiritual laws over physical ones. In Christian education, morality is not just a useful application to science - it determines the very structure of the physical world and directly influences it, and therefore it is a law-making force [6].

The main activity of the modern Sunday schools is spiritual education of students, and the main tasks of work of the Sunday schools are the following:

- to awaken the child's consciousness;

- to direct to the knowledge of the world;

- to help to realize oneself in this world;

- to form religious feelings;

- to raise children on Christian principles;

- to teach the basics of Christian doctrine;

- to form church life skills;

- to raise children's sense of reverence for shrines, respect and love for parents and other people;

- to teach children a careful attitude towards the surrounding world;

- to promote the development of creative abilities, intellectual and physical perfection of the child;

- to unite the children of the church community;

- to teach the children to be reciprocal;

- to bring up mutual understanding;

- to promote the development of creative abilities.

In order to find out the peculiarities of the process of spiritual education in out-of-school education institutions, the author selected three largest denominations in Ukraine - Orthodoxy, Catholicism, and Protestantism. According to the Department of Religious Affairs and Nationalities of the Ministry of Culture of Ukraine, on January 1, 2016, more than 10,000 Sunday schools operated in Ukraine [7].

Of course, the main subject in every Sunday school is the Law of God. The Bible is the basis for the work of Sunday schools of different denominations. Although the purpose of the school may sound differently, the goal of each school, regardless of confessional affiliation, is the spiritual upbringing of the child.
Each Church has its own educational program for Sunday school. But as practice shows, most teachers can adjust curricula adapting to different nuances. It depends on the specifics of each Sunday school. For example, some Sunday schools do not have a room that would allow children to be separated by age. It's impossible to tell young children the topics that are intended for middle-aged or older children. Therefore, teachers can improvise at lessons. The main thing is to follow the main goal of each Sunday school - spiritual upbringing of children. Some Sunday schools have detailed planning of the lessons. An example is the Sunday School "Chado" (Child) at the St. Michael's Golden-Domed Monastery in Kiev, which conducts its lessons according to the book "The Scriptures", composed of a series of 12 textbooks for teaching the Law of God in Sunday schools.

The textbook is prepared by the teacher Natalia Vashchenko on the basis of many years of her teaching experience, as well as a course of teaching at the Sunday school for children. The school has its own website, where each teacher can find information on the development of lessons for different age categories. The lessons include presentation, a workbook, various games and cartoons, which are adapted for a specific topic.

In addition to Christian disciplines, special importance is given to additional developmental activities in circles and sections aimed at the comprehensive development of the individual. This includes choral singing, choreography, needlework, fine arts, and others. Typically, the lessons of creativity are based on the topic that was studied in a class on this day. Hand-made works are usually adapted to the studied event or character.

The investigated religious organizations create clubs of interest for young people; organize events for Sunday school students. Meetings of young people for communicating and discussing the studied topics in an informal setting are inherent in many Sunday schools of different denominations. Each confession organizes children's camps at Sunday school. These are usually summer camps, tent cities. Some schools have the opportunity to have children rest in winter (if they have adapted rooms). Each of these activities is a continuation of Sunday school education. And of course, the main goal - spiritual upbringing - continues. The children participate in thematic activities on the days that are adapted to a particular Christian holiday, as well as activities devoted to patriotic education.

Modern Sunday schools in Ukraine offer a solid foundation for the birth of a new generation of people with deep moral qualities that make up the alternative to the spiritual decline of society.

Spiritual education at Sunday school takes place through musical activities (at the lesson of singing), fine art (at drawing lessons), through theatrical productions, where students can not only develop actor's skills, but also form certain stereotypes of behavior aimed at the development of positive personality traits.

Various forms of classes, common prayer in the church, active participation in church service and any kind of joint work, joint tea-drinking, pilgrimage trips, participation in various competitions and events, bring children together and promote communication in which modern children and adolescents have need. Parents aren't also left behind, they are actively involved in the life of the Sunday school, they 
are involved in the educational process, continuing their coming to church, and in some cases even take an example from their children and study together the very foundations of the Orthodox faith.

Conclusions. Thus, the Sunday School not only gives children the right knowledge of God, the world and man, but it also promotes formation of a profound Christian out- look in them, firm convictions of a developed moral feeling. And also tries to solve tasks, conditioned by the current state of society: formation of spiritual and moral responsibility; study, preservation and development of national cultural and historical traditions; establish connections between spiritual, moral, civil and patriotic education.

\section{ЛІТЕРАТУРА}

1. Жигайло, Н. Психологія духовного становлення студентів вищих навчальних закладів: дис. ... док. псих. наук: 19.00.07. K., 2010, 428 c.

2. Вишневський, О. І., Кобрій, О. М., Чепіль, М. М. Теоретичні основи педагогіки: курс лекцій. Дрогобич: Відродження, 2001, 268 c.

3. Витівський, М. Християнське виховання і навчання дітей. Порадник для батьків, вихователів, учителів-катехитів. Трускавець: Катехитична Комісія СамбірськоДрогобицької Єпархії УГКЦ, 2001, С. 179-186.

4. Кодекс Канонів Східних Церков. Рим: В-во Василіян, 1993, $845 \mathrm{c}$.

5. До проблем релігійної освіти у світській державі. Режим доступу: risu.org.ua/ua/index/expert_thought/analytic/8897 (15.11.2012)

6. Історія недільних шкіл в Україні. Режим доступу :www.chado-bozhe.com.ua/article/history

7. https://www.religion.in.ua/zmi/ukrainian_zmi/32524-religijniorganizaciyi-v-ukrayini-stanom-na-1-sichnya-2016-r.html.

\section{REFERENCES}

1. Zhyhailo, N. Psychology of the spiritual formation of students of the higher education institutions: DSc thesis. K., 2010, 428p.

2. Vyshnevskyi, O. I., Kobrii, O. M., Chepil, M. M. Theoretical foundations of pedagogy: Course of lectures. Drogobych: Revival, 2001, 268 p.

3. Vytivskyi, M. Christian education and upbringing of children. Guide for parents and teachers. Truskavets, 2001, P. 179-186.

4. Code of Canons of the East Churches. Rome: Publishing house

5. To the problems of religious education in a secular state. Retrieved from: risu.org.ua/ua/index/expert_thought/analytic/8897 $(11 / 15 / 2012)$

6. The history of Sunday schools in Ukraine. Retrieved from: www.chado-bozhe.com.ua/article/history

7. https://www.religion.in.ua/zmi/ukrainian_zmi/32524-religijniorganizaciyi-v-ukrayini-stanom-na-1-sichnya-2016-r.html.

of Basilian, 1993, 845 p.

Духовное воспитание подрастающего поколения во внешкольных образовательных учреждениях современной Украины

\section{Ю. С. Шульга}

Аннотация. Статья освещает особенности духовного воспитания подрастающего поколения во внешкольных образовательных учреждениях современной Украины. Раскрыто понятие воскресной школы как типа внешкольного образовательного учреждения. Определена роль воскресной школы в процессе духовного воспитания и образования подрастающего поколения. Охарактеризованы задания и деятельность воскресных школ различных конфессий. Проанализированы формы работы с детьми в воскресных школах.

Ключевые слова: духовное воспитание, внешкольное образовательное учреждение, дети, христианство. 